\title{
Antimicrobial use prior as a risk factor for developing extended-spectrum beta-lactamse- producing Klebsiella spp. in South Brazil
}

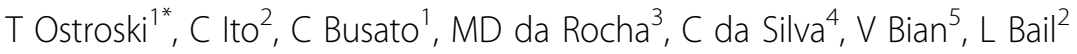 \\ From International Conference on Prevention \& Infection Control (ICPIC 2011) \\ Geneva, Switzerland. 29 June - 2 July 2011
}

\section{Introduction / objectives}

Extended-spectrum beta-lactamase-producing (ESBL) Klebsiella spp. is a problematic nosocomical pathogen around the world. In the present study, we aimed to evaluate the previous use of antibiotics as a risk factor for isolation of ESBL Klebsiella spp.

\section{Methods}

In aÂ retrospective case control study between June 2009 and June 2010 at Santa Casa de Misericórdia Hospital, city of Ponta Grossa, south Brazil, 61 Klebsiella spp. (29 ESBL and 32 controls non-ESBL-producing isolates) were enrolled. ESBL were screened by disk diffusion method and double disk approximation method, according to CLSI. Prior use of antibiotic was analyzed in electronic medical records. The antibiotic consumption (DDDs defined daily doses) was tested using the $\mathrm{X}^{2}$ test $(p<0.05)$.

\section{Results}

The DDDs of prior use and full use of cephalosporines, fluoroquinolones, e metronidazole in ESBL and non-ESBL groups were (122.02/145.77; 8.78/69.07), (15.66/22; 0.01/ $26.2)$, (47.33/47.66; 3/28) respectively. Prior use of cephalosporines, fluoroquinolones, and metronidazole was higher in ESBL-Klebsiella spp. than non-ESBL-Klebsiella spp. $(p<0,001)$. CarbapenemsÂ were not used by the control group.

\section{Conclusion}

Theprior use of broad-spectrum cephalosporins, fluoroquinolones and metronidazole is an important risk factor for acquisition of ESBL producing Klebsiella spp.

Departamento de Medicina, Universidade Estadual de Ponta Grossa, Ponta Grossa, Brazil

Full list of author information is available at the end of the article

\section{Disclosure of interest}

None declared.

\section{Author details}

${ }^{1}$ Departamento de Medicina, Universidade Estadual de Ponta Grossa, Ponta Grossa, Brazil. ${ }^{2}$ Análises Clínicas e Toxicológicas, Universidade Estadual de Ponta Grossa, Ponta Grossa, Brazil. ${ }^{3}$ Departamento de Saúde Pública, Universidade Estadual de Ponta Grossa, Ponta Grossa, Brazil. ${ }^{4}$ Intensive Care Unit, Santa Casa de Misericórdia, Ponta Grossa, Brazil. ${ }^{5}$ Pharmacy, Santa Casa de Misericórdia, Ponta Grossa, Brazil.

Published: 29 June 2011

\section{doi:10.1186/1753-6561-5-S6-P138}

Cite this article as: Ostroski et al:: Antimicrobial use prior as a risk factor for developing extended-spectrum beta-lactamse-producing Klebsiella spp. in South Brazil. BMC Proceedings 2011 5(Suppl 6):P138.
Submit your next manuscript to BioMed Central and take full advantage of:

- Convenient online submission

- Thorough peer review

- No space constraints or color figure charges

- Immediate publication on acceptance

- Inclusion in PubMed, CAS, Scopus and Google Scholar

- Research which is freely available for redistribution
() Biomed Central

\section{Biomed Central}

